\title{
Therapeutic Approach of Fetal Thyroid Disorders
}

\author{
Michel Polak $^{\mathrm{a}}$ Guy Van Vliet ${ }^{\mathrm{b}}$ \\ a Université Paris Descartes, Pediatric Endocrinology, Hôpital Necker Enfants Malades, AP-HP, INSERM U845, \\ Paris, France; bepartment of Pediatrics, University of Montreal, Montreal, Qué., Canada
}

\section{Key Words}

Graves' disease $\cdot$ Hypothyroidism $\cdot$ Fetal goiter

\begin{abstract}
Recent advances in fetal imaging techniques and fetal hormonology allow the identification in the fetus of thyroid function disorders that can potentially be treated in utero by giving drugs to the mother. In women with Graves' disease (when fetal hyperthyroidism is present), it can generally be treated in a noninvasive way by optimizing treatment of the mother. For goitrous nonimmune fetal hypothyroidism leading to hydramnios, intra-amniotic injections of thyroxine have been reported to decrease the size of the fetal thyroid. Experience with such a procedure is limited and the risk of provoking premature labor or infections should be carefully evaluated. Thus, follow-up of the efficacy and the possible long-term undesired consequences of medical interventions administered to the fetus are of great importance. Such interventions should only be performed by specialized teams with extensive experience in perinatal care.
\end{abstract}

Copyright $\odot 2010$ S. Karger AG, Basel

\section{Introduction}

The importance of adequate control of maternal iodine nutrition to ensure normal fetal thyroid function and therefore normal fetal maturation, especially of the brain, has long been appreciated. Advances in prenatal imaging and fetal hormonology have enabled the identification of some severe, but treatable, thyroid disorders in the fetus and, therefore, the fetus has become a patient in its own right. The potential benefits to the fetus, however, must be carefully weighed against potential risks to the fetus and mother.

\section{Fetal Hypothyroidism}

Iodine is the micronutrient required for the manufacture of thyroid hormone. The placenta expresses the sodium-iodine symporter throughout gestation, which probably explains why the mother's iodine status is critical for the fetus [1]. If the mother's iodine intake is low, the fetal thyroid cannot build appropriate stores of iodine and fetal hypothyroidism may ensue. Worldwide, suboptimal maternal iodine intake leading to endemic cretinism remains a major public health problem [2]. Supplying the mother with iodine to prevent this condition is arguably one of the best examples of considering the fetus as a patient and treating this patient by giving the medication to the mother (table 1) $[3,4]$. However, excess iodine load in the mother during pregnancy may also cause goiter in the fetus. This goiter may decrease in size if the iodine supply is decreased or if in utero treatment by intraamniotic injections of thyroxine is given to the fetus, as described below [5].

\section{KARGER \\ Fax +4161306 1234 \\ E-Mail karger@karger.ch}

www.karger.com (c) 2010 S. Karger AG, Basel

1663-2818/10/0741-0001\$26.00/0

Accessible online at:

www.karger.com/hrp
Michel Polak, MD, PhD

Pediatric Endocrinology, Hôpital Necker Enfants Malades

149 , rue de Sèvres

FR-75015 Paris (France)

Tel. +33 1444948 03, Fax +331443816 48, E-Mail michel.polak@nck.aphp.fr 
In the past 20 years, several studies have demonstrated that $\mathrm{T}_{4}$ can cross the placenta in substantial amounts. The $\mathrm{T}_{4}$ that is detectable in human embryonic tissues, before the onset of fetal thyroid function, must be of maternal origin [6]. The $\mathrm{T}_{4}$ that can be measured in cord blood from neonates with complete absence of thyroid function (which is $30-50 \%$ that of normal neonates) must be of maternal origin [7]. More recently, Anselmo et al. [8] have shown that normal neonates born to a mother with chronically raised $\mathrm{T}_{4}$ levels due to a mutation inactivating the thyroid hormone receptor have lowered plasma thyrotropin levels. Lastly, the expression of the thyroid hormone transporter MCT8, which preferably transports $\mathrm{T}_{4}$, but also $T_{3}$, by the human placenta increases throughout gestation [9]. Taken together, these data indicate that maternal $\mathrm{T}_{4}$ can cross the placenta in physiologically relevant amounts.

Pathological conditions illustrate the clinical importance of this transplacental transfer of $\mathrm{T}_{4}$ from mother to fetus. In an infant with central hypothyroidism caused by a maternally inherited heterozygous mutation inactivating PIT1 and whose mother was untreated, severe developmental delay occurred [10]. Indeed in that case, both the mother and the fetus had hypothyroidism, and no rescue (through $\mathrm{T}_{4}$ transplacental transfer) of the fetal thyroid function from this mother, who had untreated hypothyroidism, was possible [10]. Of potentially much greater public health importance, Haddow et al. [11] and Pop et al. [12] found that children born to mothers who have low $\mathrm{T}_{4}$ levels during pregnancy have IQ 4-7 points lower than controls. Therefore, women with a personal or family history of hypothyroidism should be screened for hypothyroidism when they plan a pregnancy or as soon as pregnancy is confirmed (table 1) [13]. In women who are already receiving levothyroxine, an increase in dose of about $30-50 \%$ during pregnancy is generally required [14].

If the fetus has severe thyroid dyshormonogenesis, transplacental transfer of $\mathrm{T}_{4}$ is not always sufficient to prevent the development of fetal goiter. These fetal goiters can sometimes become big enough to cause hydramnios or to impede vaginal delivery. In these cases, levothyroxine can be injected into the amniotic fluid, which is then swallowed by the fetus leading to a decrease in the size of the fetal thyroid and in the degree of hydramnios, allowing vaginal delivery [15]. Even if the decrease in the thyroid volume is paralleled by a certain degree of decrease in fetal TSH level, the exact role of the TSH in the thyroid volume development in utero remains to be fully understood [15]. A procedure that is even riskier than injections
Table 1. Screening, prevention and management of fetal hypothyroidism

Adequate iodine intake should be ensured for all pregnant women (250 $\mu$ g daily)

For women with a personal or family history of thyroid disease, measure plasma TSH and free $\mathrm{T}_{4}$ levels before, at the beginning and during pregnancy

On ultrasonography at around 22 and 32 gestational weeks, measure fetal thyroid diameter and circumference: if above the 95th percentile for gestational week, consider fetal thyroid disorder

If thyroxine treatment is given to a pregnant woman, ensure adequate increase in dose throughout pregnancy

If fetal goiter is documented, consider cordocentesis and fetal blood $\mathrm{T}_{4}$ and $\mathrm{TSH}$ determination, and intra-amniotic thyroxine injections if severe hypothyroidism is diagnosed

into the amniotic cavity, i.e. injection of levothyroxine into the umbilical vein, should be restricted to progressive hydramnios in spite of repeated intra-amniotic injections [16]. However, the identification of a fetal goiter is exceedingly rare. Most dyshormonogenetic goiters are missed on clinical examination at birth [17] and are only revealed on investigation of congenital hypothyroidism by ultrasonography or nuclear imaging. On the other hand, the fetal brain is, to a large extent, protected from defective fetal thyroid hormone production not only through the transplacental transfer of maternal thyroxine, as described above, but also from upregulation of brain type 2 deiodinase, which converts $\mathrm{T}_{4}$ into $\mathrm{T}_{3}$ [18]. These two mechanisms likely account for the observation that intellectual outcome is most often normal if treatment is instituted shortly after birth, even in congenital hypothyroidism with delayed bone maturation at diagnosis (indicating a prenatal onset) $[19,20]$. Therefore, the in utero treatment of fetal hypothyroidism should mostly be considered when a fetal goiter causes hydramnios or is likely to impede vaginal delivery [21].

More frequently, it is the ability of antithyroid drugs to cross the placenta that leads to hypothyroidism and goiter in fetuses born by women receiving this therapy for Graves' disease. Dose reduction should restore normal fetal thyroid function and decrease the size of the fetal thyroid (table 1) [22]. These women should be carefully monitored by at least monthly $\mathrm{T}_{4}, \mathrm{~T}_{3}$ and $\mathrm{TSH}$ blood determinations and the dosing of antithyroid drugs reduced to the minimum dose to maintain the maternal $\mathrm{T}_{4}$ in the 
Table 2. Screening and prevention of fetal hyperthyroidism

Be suspicious of fetal hyperthyroidism if:

- Hyperthyroidism is diagnosed for the first time during pregnancy

- A present or past Graves' disease exists and if the woman is taking antithyroid therapy during pregnancy

- Mother has a history of previous antithyroid therapy and especially a history of ablation therapy $\left({ }^{131} \mathrm{I}\right.$, surgery) as thyroidstimulating immunoglobulins may persist

- During the last trimester, the mother is positive for thyroidstimulating immunoglobulins

- Mother taking antithyroid drugs during the last trimester of pregnancy

- Mutations causing an increase in the constitutive activity of the TSH receptor

Features of fetal hyperthyroidism:

- Impaired growth and bone maturation (distal femoral center at 32 weeks' gestation)

- Fetal tachycardia when severe hyperthyroidism

- Increased size of thyroid gland (perimeter and circumference on ultrasonography)

- $\mathrm{TSH}$, free $\mathrm{T}_{4}$ and free $\mathrm{T}_{3}$ on cordocentesis ${ }^{\mathrm{a}}$

${ }^{a}$ Fetal blood sampling should be considered only when fetal thyroid status cannot be inferred from echography and if in utero treatment is considered.

upper normal range using trimester-specific norms of $\mathrm{T}_{4}$ during pregnancy.

It is important to note that measuring TSH and thyroid hormone levels in the amniotic fluid, which harbors a lower risk than umbilical vein sampling, is less accurate and does not reflect fully the fetal thyroid function. Indeed, we had the opportunity to have both measurements in one fetus of our study: the fetal cord blood levels were in the hypothyroid range, whereas the amniotic fluid levels would have been said to be normal [15].

\section{Fetal Hyperthyroidism}

Fetal hyperthyroidism most commonly occurs in the context of maternal Graves' disease, although other risk factors do exist (table 2). Present or past Graves' disease in women of childbearing age is common, estimated to be $1 \%$ of pregnant women. Overt fetal hyperthyroidism in the offspring of these women is very rare, having a prevalence in neonates at risk of $1 \%$ or less. It is, however, a serious condition that can be associated with fetal death or long-term sequellae [23]. The disease is due to thyroid- stimulating immunoglobulins being transferred from the maternal into the fetal compartment, leading to stimulation of the fetal thyroid by activation of the TSH receptor. Fetal thyroid hormone secretion is consequently increased, causing thyrotoxicosis in utero and then postnatally until the maternal antibodies have disappeared from the infant's circulation (by 4 months of age at most and on average by 1 month of age) [24].

The fetal thyroid gland starts secreting thyroid hormone at about 10 weeks of gestation. The TSH receptor starts responding to the stimulation of TSH, and therefore to the stimulation by thyroid-stimulating immunoglobulins, during the second trimester of gestation. The fetal concentration of IgG-type immunoglobulins, in particular thyroid-stimulating immunoglobulins, increases progressively to reach the maternal level at around 30 weeks of gestation. As there is a correlation between the elevated level of transmitted antibodies and the appearance of thyrotoxicosis, fetal hyperthyroidism develops during the second half of gestation, mostly in fetuses born by women with high levels of thyroid-stimulating immunoglobulins. TSH-receptor-blocking antibodies might also be present in pregnant women with Graves' disease or in rare cases in which hypothyroidism in the mother is caused by TSH-blocking antibodies $[25,26]$. The transplacental passage of these blocking antibodies has also been demonstrated, and the clinical symptoms in the fetus are the result of the imbalance between the stimulating action of the thyroid-stimulating immunoglobulins and the inhibitory action of the TSH-receptorblocking antibodies.

Even more rarely, fetal hyperthyroidism results from mutations causing an increase in the constitutive activity of the TSH receptor (table 2). These mutations can occur de novo, in the germline or at the somatic level in a thyroid nodule, or may be dominantly inherited [27-29]. A particularly severe de novo germline mutation has been reported to result in developmental delay [30]. However, fetal hyperthyroidism from any cause has potentially harmful effects; therefore, antenatal treatment by giving drugs to the mother is important.

Fetal tachycardia is an alarm signal for hyperthyroidism (table 2), but occurs later than fetal goiter. Goiter is, therefore, the earliest sonographic sign of fetal thyroid dysfunction [31]. Data on the normal size of the fetal thyroid gland, according to gestational age, have been reported [32]. Accelerated bone maturation might be detected by neonatal ultrasonography in relation to fetal hyperthyroidism. Fetal hyperthyroidism might also be associated with intrauterine growth retardation, and pre- 
mature birth is frequent if fetal hyperthyroidism is left untreated.

When a fetal goiter is detected on ultrasonography, the presence of current or past Graves' disease in the mother must be investigated. In pregnant women being treated with antithyroid drugs, a fetal goiter might be due to overtreatment resulting in fetal hypothyroidism or to fetal hyperthyroidism from transplacental passage of thyroid-stimulating immunoglobulins. The functional status of the fetal thyroid can generally be inferred from the dose of antithyroid drug given to the mother, the maternal titer of thyroid-stimulating immunoglobulins and by the echographic characteristics of the fetal goiter when assessed by experienced radiologists [31]. Rarely is a formal diagnosis based on fetal blood samples obtained by cordocentesis necessary to measure fetal circulating TSH and $\mathrm{T}_{4}$ levels (table 2) [31]. The risk of this latter procedure should be weighed against its benefit, and is usually restricted to cases where the distinction between a fetal goiter with hypothyroidism due to excess antithyroid drugs given to the mother or with fetal hyperthyroidism due to insufficient maternal treatment cannot be made otherwise.

The treatment of hyperthyroidism in the fetus by administering antithyroid drugs to the mother is effective and safe. Sometimes, the dose of antithyroid drugs that is required to control hyperthyroidism in the fetus leads to hypothyroidism in the mother, in which case thyroxine should be given to the mother [31]. In pregnant women, propylthiouracil is preferred to methimazole or carbimazole because the latter has been associated with aplasia cutis congenita and other malformations (table 2) [33].

In pregnant women with current or past Graves' disease, assays to measure thyroid-stimulating immuno- globulin levels should be performed routinely at the beginning of pregnancy. In pregnant women who are taking antithyroid therapy and/or who have positive results for thyroid-stimulating immunoglobulins, monthly ultrasound imaging might be justified after 20 weeks of gestation to monitor whether evidence of thyroid dysfunction, including goiter, is developing in the fetus. Imaging should be performed by an experienced radiologist.

Fetal hyperthyroidism may occur in fetuses born by women receiving long-term levothyroxine after thyroidectomy or radioiodine treatment for Graves' disease since thyroid-stimulating immunoglobulins can persist for many years in such women. In pregnant women with a history of Graves' disease, but negative thyroid-stimulating immunoglobulin who are receiving no antithyroid treatment, routine prenatal care suffices.

\section{Conclusions}

Several interventions have been proposed to improve fetal outcomes of fetal thyroid disorders by considering the fetus as the patient to treat. These range from public health interventions with clear benefits and negligible risks, such as increasing the iodine intake of all pregnant women, to procedures with a much less clear benefit-torisk ratio, such as cordocentesis for determining thyroid function in a fetus with a goiter [34]. Thus, follow-up of the efficacy and the possible long-term consequences of medical interventions administered to the fetus are of great importance. Such very specific care of the fetus should be conducted by a specialized team with extensive experience in prenatal care.

\section{References}

$>1$ Di Cosmo C, Fanelli G, Tonacchera M, Ferrarini E, Dimida A, Agretti P, De Marco G, Vitti P, Pinchera A, Bevilacqua G, Naccarato AG, Viacava P: The sodium-iodide symporter expression in placental tissue at different gestational age: an immunohistochemical study. Clin Endocrinol (Oxf) 2006;65:544548.

-2 Cao XY, Jiang XM, Dou ZH, Rakeman MA, Zhang ML, O’Donnell K, Ma T, Amette K, DeLong N, DeLong GR: Timing of vulnerability of the brain to iodine deficiency in endemic cretinism. N Engl J Med 1994;331: 1739-1744. $\checkmark 3$ Delange F, de Benoist B, Pretell E, Dunn JT: Iodine deficiency in the world: where do we stand at the turn of the century? Thyroid 2001;11:437-447.

$\checkmark 4$ Glinoer D: The importance of iodine nutrition during pregnancy. Public Health Nutr 2007; 10:1542-1546.

5 Serreau R, Polak M, Leger J, Vuillard E, Thurninger O, Chemouny S, Heid M, Guibourdenche J, Jacqz-Aigrain E, Oury JF, Luton D: Fetal thyroid goiter after massive iodine exposure. Prenat Diagn 2004;24:751753.
-6 Calvo RM, Jauniaux E, Gulbis B, Asunción M, Gervy C, Contempré B, Morreale de Escobar G: Fetal tissues are exposed to biologically relevant free thyroxine concentrations during early phases of development. J Clin Endocrinol Metab 2002;87:1768-1777.

7 Vulsma T, Gons MH, de Vijlder JJ: Maternalfetal transfer of thyroxine in congenital hypothyroidism due to a total organification defect of thyroid agenesis. N Engl J Med 1989;321:13-16.

8 Anselmo J, Cao D, Karrison T, Weiss RE, Refetoff S: Fetal loss associated with excess thyroid hormone exposure. JAMA 2004;292: 691-695. 
9 Chan SY, Franklyn JA, Pemberton HN, Bulmer JN, Visser TJ, McCabe CJ, Kilby MD: Monocarboxylate transporter 8 expression in the human placenta: the effects of severe intrauterine growth restriction. J Endocrinol 189:465-471.

10 de Zegher F, Pernasetti F, Vanhole C, Devlieger $H$, Van den Berghe G, Martial JA: The prenatal role of thyroid hormone evidenced by fetomaternal Pit-1 deficiency. J Clin Endocrinol Metab 1995;80:3127-3130.

- 11 Haddow JE, Palomaki GE, Allan WC, Williams JR, Knight GJ, Gagnon J, O’Heir CE, Mitchell ML, Hermos RJ, Waisbren SE, Faix JD, Klein RZ: Maternal thyroid deficiency during pregnancy and subsequent neuropsychological development of the child. N Engl J Med 1999;341:549-555.

-12 Pop VJ, Kuijpens JL, van Baar AL, Verkerk G, van Son MM, de Vijlder JJ, Vulsma T, Wiersinga WM, Drexhage HA, Vader HL: Low maternal free thyroxine concentrations during early pregnancy are associated with impaired psychomotor development in infancy. Clin Endocrinol 1999;50:147-148.

13 Glinoer D and Delange F: The potential repercussions of maternal, fetal, and neonatal hypothyroxinemia on the progeny. Thyroid 2000;10:871-887.

14 Alexander EK, Marqusee E, Lawrence J, Jarolim P, Fischer GA, Larsen PR: Timing and magnitude of increases in levothyroxine requirements during pregnancy in women with hypothyroidism. N Engl J Med 2004; 351:241-249.

15 Ribault V, Castanet M, Bertrand AM, Guibourdenche J, Vuillard E, Luton D, Polak M, the French Fetal Goiter Study Group: Experience with intraamniotic thyroxine treatment in nonimmune fetal goitrous hypothyroidism in 12 cases. J Clin Endocrinol Metab 2009;94:3731-3739.

-16 Börgel K, Pohlenz J, Holzgreve W, Bramswig $\mathrm{JH}$ : Intrauterine therapy of goitrous hypothyroidism in a boy with a new compound heterozygous mutation (Y453D and C800R) in the thyroid peroxidase gene. A long-term follow-up. Am J Obstet Gynecol 2005; 193: 857-858.
17 Cavarzere P, Castanet M, Polak M, Raux-Demay MC, Cabrol S, Carel JC, Léger J, Czernichow P: Clinical description of infants with congenital hypothyroidism and iodide organification defects. Horm Res 2008;70: 240-248.

18 Calvo R, Obregón MJ, Ruiz de Oña C, Escobar del Rey F, Morreale de Escobar G: Congenital hypothyroidism, as studied in rats. Crucial role of maternal thyroxine but not of 3,5,3 [prime]-triiodothyronine in the protection of the fetal brain. J Clin Invest 1990;86: 889-899.

19 Dubuis JM, Glorieux J, Richer F, Deal CL, Dussault JH, Van Vliet G: Outcome of severe congenital hypothyroidism: closing the developmental gap with early high dose levothyroxine treatment. J Clin Endocrinol Metab 1996;81:222-227.

20 Simoneau-Roy J, Marti S, Deal C, Huot C, Robaey P, Van Vliet G: Cognition and behavior at school entry in children with congenital hypothyroidism treated early with high-dose levothyroxine. J Pediatr 2004; 144 : 747-752.

21 Perelman AH, Johnson RL, Clemons RD, Finberg HJ, Clewell WH, Trujillo L: Intrauterine diagnosis and treatment of fetal goitrous hypothyroidism. J Clin Endocrinol Metab 1990;71:618-621.

22 Davidson KM, Richards DS, Schatz DA, Fisher DA: Successful in utero treatment of fetal goiter and hypothyroidism. N Engl J Med 1991;324:543-546.

23 Polak M, Le Gac I, Vuillard E, Guibourdenche J, Leger J, Toubert ME, Madec AM, Oury JF, Czernichow P, Luton D: Fetal and neonatal thyroid function in relation to maternal Graves' disease. Best Pract Res Clin Endocrinol Metab 2004;18:289-302.

24 Zakarija M and McKenzie JM: Pregnancyassociated changes in the thyroid-stimulating antibody of Graves' disease and the relationship to neonatal hyperthyroidism. J Clin Endocrinol Metab 1983;57:1036-1040.

25 Karlsson FA, Dahlberg PA, Ritzén EM: Thyroid blocking antibodies in thyroiditis. Acta Med Scand 1984;215:461-466.

26 Pacaud D, Huot C, Gattereau A, Brown RS, Glorieux J, Dussault JH, Van Vliet G: Outcome in three siblings with antibody-mediated transient congenital hypothyroidism. J Pediatr 1995;127:275-277.
27 Kopp P, van Sande J, Parma J, Duprez L, Gerber H, Joss E, Jameson JL, Dumont JE, Vassart G: Brief report: congenital hyperthyroidism caused by a mutation in the thyrotropin-receptor gene. $\mathrm{N}$ Engl J Med 1995;332:150-154.

28 Kopp P, Muirhead S, Jourdain N, Gu WX, Jameson JL, Rodd C: Congenital hyperthyroidism caused by a solitary toxic adenoma harboring a novel somatic mutation (serine 281->isoleucine) in the extracellular domain of the thyrotropin receptor. J Clin Invest 1997;100:1634-1639.

29 Duprez L, Parma J, Van Sande J, Allgeier A, Leclère J, Schvartz C, Delisle MJ, Decoulx M, Orgiazzi J, Dumont J, Vassar G: Germline mutations in the thyrotropin receptor gene cause non-autoimmune autosomal dominant hyperthyroidism. Nat Genet 1994;7: 396-401.

30 de Roux N, Polak M, Couet J, Leger J, Czernichow P, Milgrom E, Misrahi M: A neomutation of the thyroid-stimulating hormone receptor in a severe neonatal hyperthyroidism. J Clin Endocrinol Metab 1996;81:20232026.

31 Luton D, Le Gac I, Vuillard E, Castanet M, Guibourdenche J, Noel M, Toubert ME, Léger J, Boissinot C, Schlageter MH, Garel C, Tébeka B, Oury JF, Czernichow P, Polak M: Management of Graves' disease during pregnancy: the key role of fetal thyroid gland monitoring. J Clin Endocrinol Metab 2005; 90:6093-6098.

32 Ranzini AC, Ananth CV, Smulian JC, Kung M, Limbachia A, Vintzileos AM: Ultrasonography of the fetal thyroid: nomograms based on biparietal diameter and gestational age. J Ultrasound Med 2001;20:613-617.

-33 Foulds N, Walpole I, Elmslie F, Mansour S: Carbimazole embryopathy: an emerging phenotype. Am J Med Genet 2004;132A:130135.

34 Stoppa-Vaucher S, Francoeur D, Grignon A, Alos A, Pohlenz J, Hermanns P, Van Vliet G, Deladoëy J: Non-immune goiter and hypothyroidism in a 19-week fetus: a plea for conservative management. J Pediatr 2010, in press. 